NBER WORKING PAPER SERIES

\title{
PUBLIC SCHOOL SEGREGATION IN METROPOLITAN AREAS
}

Charles T. Clotfelter

Working Paper 6779

http://www.nber.org/papers/w6779

\section{NATIONAL BUREAU OF ECONOMIC RESEARCH \\ 1050 Massachusetts Avenue \\ Cambridge, MA 02138 \\ November 1998}

I am grateful to Randy Walsh, Thomas Anderson, and Bethany Peters for valuable research assistance. The views expressed here are those of the author and do not reflect those of the National Bureau of Economic Research.

(C) 1998 by Charles T. Clotfelter. All rights reserved. Short sections of text, not to exceed two paragraphs, may be quoted without explicit permission provided that full credit, including (C) notice, is given to the source. 
Public School Segregation in Metropolitan Areas

Charles T. Clotfelter

NBER Working Paper No. 6779

November 1998

JEL No. J15, R2, I28

\section{ABSTRACT}

This paper presents measures of segregation in public schools for metropolitan areas. It shows that, not only are metropolitan areas very segregated, most of that segregation is due to racial disparities between districts rather than segregative patterns within districts. Metropolitan areas in the South and West tend to have larger districts, and thus feature less fragmentation by school district. Segregation at the metropolitan level appears to vary systematically with size, racial mix, and region. Because larger metropolitan areas tend to have more jurisdictions and exhibit greater differences in racial composition among jurisdictions, measured segregation rises with size, as measured by school enrollment.

Charles T. Clotfelter

Box 90245

Duke University

Durham, NC 27708-0245

and NBER

Charles.Clotfelter@Duke.edu 
Clotfelter--p.3

\title{
Public School Segregation in Metropolitan Areas
}

\author{
Charles T. Clotfelter
}

Empirical studies of racial patterns of enrollment in public schools in the United States have shown that the elimination of the last vestiges of de jure segregation in the late 1960s brought about a dramatic reduction in measured segregation in that South, making the schools in that region the least segregated in the nation. ${ }^{1}$ After 1970 the principal cause of racial segregation in the nation's public schools no longer appeared to be the official policies that school districts followed to separate students by race, but rather disparities in racial composition between school districts. These disparities seemed to be most pronounced in the largest metropolitan areas, where the proportions of minority students in many central city districts exceeded 50 percent. Combined with the Supreme Court's ruling in Milliken v. Bradley (1974) preventing most desegregation plans from moving students across district boundaries, these disparities appeared to lock segregation in place in most metropolitan areas. As Orfield and Monfort (1994, p. 29) state, "The real problem of segregation was not among the students and schools within the big city district but between the city and suburban districts."

Despite the acknowledged importance of racial disparities between districts in urban areas, and the focus in some studies on large urban school districts, there actually has been very little empirical analysis of school segregation using metropolitan areas as the unit of observation. ${ }^{2}$ 
Instead, previous empirical work has examined racial patterns for regions, states, or large central city districts. Because such studies relied on data sets consisting only of samples of districts, it was impossible to put together all of the districts contained in most metropolitan areas, thus making the study of metropolitan areas simply infeasible. However, the present paper utilizes a data set that includes virtually all districts, making it possible to calculate measures of racial composition and segregation for entire metropolitan areas. These calculations provide an unusually clear picture of the degree to which interracial exposure in public schools differs both within and among metropolitan areas, allowing policy makers to assess the empirical significance of statements such as that of Orfield and Monfort quoted above.

Beyond its significance as an historical indicator of legal change, the racial segregation of urban schools remains a significant issue for several reasons. Perhaps most important, school desegregation is arguably the most important policy of American government to encourage racial integration. That integration has failed to become more complete has been viewed, on the one hand, as a failure of will by government to push for racial equality, and on the other, as a pragmatic response to the threat of white flight. ${ }^{3}$ Second, there is a continuing belief among many scholars and policy makers that racial integration of schools is the most effective route to the equalization of educational resources across racial and ethnic groups. Third, there is considerable evidence that students who attend desegregated schools have access to social networks and personal friendships that may have both economic and social influence in the lives of young people. ${ }^{4}$ Finally, the segregation of public schools may assume new significance in college admissions if laws are adopted such as that recently passed in Texas guaranteeing admission to the University of Texas for students finishing in the top 10 percent of any public high school in the 
Clotfelter--p.5

state. ${ }^{5}$

Several empirical questions motivate the paper. How do metropolitan areas compare in terms of racial composition, the exposure of students of different racial groups, and segregation? Are the patterns that have been observed on a regional basis evident when looking just at metropolitan areas? Are there systematic differences by size of metropolitan area? If metropolitan areas in the Northeast tend to be fragmented into more jurisdictions than those in the South, what difference does it make to overall patterns of racial contact and segregation? How much of the current segregation can be attributed to differences in enrollment patterns within school districts as opposed to racial disparities between districts? Is it accurate to view the South as having the least segregated public schools, when the analysis is restricted to metropolitan areas? The aim of the paper, in short, is simply to describe existing patterns of enrollment in metropolitan areas. No attention is paid here to the mechanics of desegregation policies, that is, whether school officials attempt to affect enrollment patterns with magnet schools, pairing of schools, or other types of voluntary or involuntary desegregation policies. ${ }^{6}$ Nor does the paper attempt to explain existing patterns of residential segregation, which obviously have great influence over patterns of public school enrollment. Much research has been devoted to the examination of such residential patterns $^{7}$, and it is beyond the scope of the current analysis to recapitulate or extend that research. For the more limited purposes at hand, the present paper takes those residential patterns as given, attempting rather to describe the degree of racial segregation in schools that results from those residential patterns in combination with the policies of school districts.

Section I briefly reviews the previous research upon which the present analysis builds. The second section describes the data set and the calculations used to measure racial patterns in 
enrollment, and it presents some illustrative calculations for selected metropolitan areas. Section III summarizes the variations in these measures across metropolitan areas. Section IV examines the variation in segregation among districts within metropolitan areas. Section V offers a brief conclusion.

\section{PREVIOUS RESEARCH ON PATTERNS OF SCHOOL SEGREGATION}

Because the federal government has regularly collected detailed information on the racial composition of public schools since 1968, researchers have been able to calculate precise measures of the degree of racial segregation, trends in racial composition, and the growth and decline in numbers of students in various racial and ethnic groups. ${ }^{8}$ A key to the usefulness of these data is the inclusion of information on the racial composition of individual schools.

One of the most important findings to emerge from this line of empirical research is that public schools in the South were dramatically transformed in the late 1960s from the most segregated into the least segregated among the nation's regions, a distinction they have retained since that time. Between 1968 and 1988 the percentage of black students in majority-white schools in the South increased from 19 to 44 percent; over the same period the comparable percentage increased by much less in Border states, the Midwest, and the West, and actually declined, from 33 to 23 percent, in the Northeast (Orfield and Monfort 1992, p. 14). Other findings from this research highlighted by Orfield and Monfort (1992, pp. 2, 30) and Orfield et al. (1997, p. 12) include an increase in the segregation of Hispanic students, the increasingly multiracial character of suburban school districts, and a gradual increase in most measures of segregation in the 1990s. 
Clotfelter--p.7

Most of the data used in these studies are based on biennial surveys of schools in samples of school districts, undertaken under the sponsorship of the Department of Education's Office for Civil Rights (OCR). Each year's sample is heavily weighted toward large districts, districts with high proportions of minority students, and districts subject to some type of oversight for civil rights compliance purposes. Sample weights are provided so that researchers can make projections to the universe of schools and school districts. Although these data are quite detailed for the districts that are included, the fact that they cover only a sample of districts makes them unsatisfactory for studying metropolitan areas, a drawback that has been noted in print. ${ }^{9}$ The data set used in the present paper rectifies this drawback with no loss in school-level detail.

Using the same OCR data, Rivkin (1994) offers a methodology for distinguishing two aspects of segregation relevant to the current paper. He decomposes total segregation into two parts: that attributable to segregation within school districts and that attributable to segregation between them. The between-district portion he refers to as "residential segregation," since its origin is differences in the racial compositions of various districts. Using a Gini coefficient to measure segregation, he presents a decomposition by region for the 1968-1988 period. When applied to the dramatic decline in segregation in the South, this decomposition produces a surprising finding. The South's decline actually resulted from two opposing trends. While the enforcement of desegregation orders caused the within-district measure of segregation to fall, residential segregation actually increased over the period, reflecting growing disparities among districts in their racial composition in the region (p. 285). Although this increase in residential segregation is suggestive of a tendency in the South toward greater de facto segregation, it is difficult to know for sure, given the nature of the OCR data used by Rivkin. Because the 
calculations are performed on a region-wide basis, one cannot be certain whether this trend represents the kind of geographical sorting characteristic of urban areas outside the South -- the relocation of families from central cities to suburban areas -- or simply broader population movements between states and from rural to urban areas. To determine whether this increased residential segregation arises from changes in metropolitan areas, it is necessary to examine data for such areas explicitly.

\section{DATA AND MEASURES}

The data used in the current paper are taken from the Common Core of Data, a public-use data set collected by the National Center for Education Statistics (NCES) from state education agencies. Like the more commonly used data collected by the Office for Civil Rights, this data set includes information on the racial composition of individual schools. For the 1994-95 school year, it covers virtually every school district in all but one of the lower 48 states, making possible complete coverage of the public school students in a total of 331 metropolitan areas. ${ }^{10}$ The analysis employs several conventional measures of racial composition and segregation. To measure the degree of interracial contact, measures of exposure were calculated. In general, the exposure of students of type $\mathrm{X}$ to students of type $\mathrm{Y}$ in district $\mathrm{j}$, where $t$ is the total number of students, $x$ and $y$ are the number of students of those respective groups, and $i$ denotes schools within the district, is

$$
E_{X Y}=\left\{\sum_{i} x_{i j}\left(y_{i j} / t_{i j}\right)\right\} /\left\{\sum x_{i j}\right\}
$$


This measure is interpreted as the racial composition (percentage of students in group Y) enrolled with the average student in group $\mathrm{X}$. The measure thus reflects both the overall racial composition and the distribution of students by race among schools within the district. Two versions of the exposure rate are used principally in the current paper: the nonwhite percentage in the average white child's school (referred to as the exposure rate of whites to nonwhites, $\mathrm{E}_{\mathrm{WN}}$ ) and the white percentage in the average black child's school (the exposure rate of blacks to whites, $\left.\mathrm{E}_{\mathrm{BW}}\right) .{ }^{11}$

Four principal measures are used in the present paper to reflect segregation: the percentage of black students in predominantly minority schools, the dissimilarity index, the Gini coefficient, and a measure of the gap between the actual racial exposure and the maximum that could be obtained. ${ }^{12}$ To understand the last of these, it is helpful to think of the nonwhite proportion among a metropolitan area's students as the maximum attainable exposure rate of whites to nonwhites, which would obtain if every school in the metropolitan area had the same racial composition. The gap between this theoretical maximum and the actual rate of racial contact, expressed as a proportion of the area's racial composition, represents one measure of the extent of segregation. ${ }^{13}$ Where $\mathrm{N}$ is the overall proportion of students who are nonwhite and $\mathrm{E}_{\mathrm{WN}}$ is the exposure rate of whites to nonwhites, it is:

$\mathrm{S}=\left(\mathrm{N}-\mathrm{E}_{\mathrm{WN}}\right) / \mathrm{N}$.

In the current paper, each of the last three of these measures is calculated using whites and nonwhites as the two basic groups, although the choice of groups in practice appears to make little difference to the qualitative results for most districts. ${ }^{14}$ With the exception of the dissimilarity 
Clotfelter--p.10

index, which is multiplied by 100 to conform to usual practice, each of these indices ranges from zero, signifying perfect racial balance among schools, to one, signifying total segregation.

\section{$\underline{\text { An Illustrative Metropolitan Area }}$}

To illustrate the kinds of calculations made in the present paper, Table 1 presents information for the metropolitan area of Washington, D.C. Based on data for individual schools, it can be calculated that the average white student in the District of Columbia school district attended a school with 50 percent nonwhite enrollment; this is the exposure rate of whites to nonwhites. Because nonwhites constituted 96 percent of the D.C. schools' overall enrollment, it is clear that nonwhites were not evenly distributed throughout that system's schools. The calculated segregation rate $(\mathrm{S})$ for the D.C. district is therefore $0.48(=(96-50) / 96)$. This rate is by far the highest of any of the 15 districts in the metropolitan area, which showed an overall rate of 0.40. Perhaps surprisingly, the Washington, D.C. school district is by no means the largest one in the metropolitan area. In fact, it is the fourth largest, following Fairfax County, Prince Georges County, and Montgomery County. Nor is the D.C. school district the only one that has a significant minority population. Fully 80 percent of Prince Georges County's enrollment is made up of nonwhite students. None of these other large districts, or indeed any of the metropolitan area's districts, exhibited the same degree of segregation as that of the D.C. schools. The size and variety of suburban districts such as those shown here illustrate one danger of focusing exclusively on city school districts.

\section{Decomposing Measured Segregation}


Clotfelter--p.11

Because the current paper seeks to distinguish segregation that is due to policies within districts from segregation arising from racial disparities between districts, it is useful to decompose observed rates of segregation. For the Gini coefficient, Rivkin (1994) offers a useful decomposition, which may be applied to a metropolitan area as follows. Let $\mathrm{G}$ be the calculated value of the Gini coefficient for all schools in all districts in the metropolitan area. A second Gini coefficient, $\mathrm{G}_{1}$, is calculated using districts in place of schools as the unit of calculation. Since it ignores any variations in racial composition within districts, this index will typically have a lower value than $\mathrm{G}$. The difference between the two indices, $\mathrm{G}_{2}=\mathrm{G}-\mathrm{G}_{1}$, is taken to measure the amount of segregation that can be attributed to segregation within districts. In the extraordinary case in which all schools within each district were racially balanced, the only source of segregation being differences in the racial composition of districts, $G$ and $G_{1}$ would have the same value, making the within-district segregation zero.

The segregation measure $\mathrm{S}$ based on exposure rates can also be decomposed easily. Consider the hypothetical exposure rate for the metropolitan area that would occur if each district were to racially balance its schools. Just as any district's racial composition (measured by the percent nonwhite, $\mathrm{N}$ ) represents the maximum attainable exposure rate of whites to nonwhites, the maximum exposure rate for the metropolitan area that could be achieved within the constraints imposed by the existing racial compositions of school districts this hypothetical rate. Where this hypothetical exposure rate is $\mathrm{E}^{*}$, the gap that is due to inter-district disparities between districts is $\mathrm{S}_{1}=\left(\mathrm{N}-\mathrm{E}^{*}\right) / \mathrm{N}$. The gap due to segregation within districts is $\mathrm{S}_{2}=\mathrm{S}-\mathrm{S}_{1}=\left(\mathrm{E}^{*}-\mathrm{E}\right) / \mathrm{N}$, that is, the difference between the exposure rate if all districts were racially balanced and the actual exposure rate, as a proportion of the overall nonwhite proportion. 
Clotfelter--p.12

\section{RACIAL PATTERNS IN METROPOLITAN AREAS}

In order to examine segregation by metropolitan area, the districts in the Common Core data were organized into Metropolitan Statistical Areas (MSA's) and Primary Metropolitan Statistical Areas (PMSA's), based on the Census Bureau's 1990 definitions. Districts outside of metropolitan areas were dropped from consideration. According to these definitions, there were 331 metropolitan areas. Data for these areas are summarized in the present paper by size and region. By size, the metropolitan areas were divided into four groups based on public school enrollment: under 50,000,50,000 up to $150,000,150,000$ up to 350,000 , and 350,000 and above. ${ }^{15}$ Despite its small number of areas, the 350,000 and over size category contained over a third of all public school students in metropolitan areas. The next two categories each accounted for about a quarter each. In addition, metropolitan areas are divided into five regions: South, Border, Northeast, Midwest, and West. ${ }^{16}$ For each metropolitan area, data for all school districts and other independent educational jurisdictions are used to make calculations similar to those presented in Table 1. It is worth mentioning that many jurisdictions in the nation's urban areas, mostly specialized or consolidated districts, are quite small. For example, the 165 jurisdictions in the Philadelphia metropolitan area include not only the Philadelphia city system, with over 200,000 students, but also another 55 that have fewer than 1,000 students each. These small units include districts for dozens of small townships and a handful of regional schools. ${ }^{17}$ Although these are not all geographically distinct districts such as the 15 shown for the Washington, D.C. area, they represent a part of the fragmentation that characterizes many large metropolitan areas.

\section{$\underline{\text { The Largest Metropolitan Areas }}$}


Clotfelter--p.13

Table 2 presents summary information on the 18 largest metropolitan areas, those with enrollments of 350,000 or more. As is evident from the second column, these large metropolitan areas were indeed fragmented, with the number of districts ranging from seven in Baltimore to 206 in Chicago. The areas' racial compositions varied widely. The nonwhite percentage ranged from a low of 15.6 percent in Minneapolis-St. Paul to a high of 78.0 percent in Los Angeles. Hispanic students outnumbered black students in Houston and the five western areas, while these two minority groups were roughly equal in size in Dallas and New York. As shown by the exposure rate, white students on average were exposed to the highest percentages of nonwhite students in Los Angeles, Riverside, and New York. As shown in column (8), which gives the segregation index $\mathrm{S}$, these rates of exposure fell short of the overall nonwhite percentages by the greatest degree in Detroit, Chicago, Philadelphia, and Baltimore. The least severe segregation was evident in Riverside and San Diego. The alternative measure of segregation based on the Gini coefficient, shown in column (11), yields a very similar ranking of most and least segregated metropolitan areas.

The table also provides information relevant to the source of the measured segregation. Column (9), based on the gap between district exposure rates and the nonwhite percentage, shows the gap that can be attributed to differences among jurisdictions in racial composition. Consider the case of Atlanta, where the gap-based measure of segregation is 0.52 ((41.119.9)/41.1). If each of the 23 districts in the Atlanta area were to balance its schools racially, the white exposure rate to nonwhites would be 26.2 percent, rather than the actual 19.9 percent that was observed. This hypothetical balancing would yield a gap-based segregation index of 0.36 rather than the actual index of 0.52 . The remaining $0.15((26.2-19.9) / 41.1)$, or about 30 percent 
of the whole gap, is due to segregation within districts. Thus 70 percent of Atlanta's public school segregation can be attributed to disparities among districts in racial composition. ${ }^{18}$ Although this share due to between-district differences is large, it is in fact smaller than average among these large metropolitan areas. For Detroit, fully 96 percent of the observed segregation was due to such between-district differences. The alternate measure based on the Gini coefficient, shown in columns (11) to (13) yields a similar story. Based on the decomposition suggested by Rivkin, column (12) shows the Gini measure of segregation that can be attributed to betweendistrict differences. Comparing that measure to the Gini coefficient calculated for schools in (11) shows the overwhelming importance of between-district disparities; those disparities account for 97 percent of the school-based Gini coefficient in three metropolitan areas: Boston, Long Island, and Detroit. By both measures, the metropolitan area where between-district segregation was least important was New York. For all but that one case, however, between-district differences were responsible for the bulk of school segregation in the largest metropolitan areas.

The table's last column shows another, more intuitive measure of segregation, the percentage of black students who attended schools that were 90 percent or more nonwhite. Although this measure is not a "fair" comparison, since it depends on an area's overall racial composition, it yields a more comprehensive measure of racial isolation than other commonly used metrics. By this measure, blacks were most likely to attend predominantly nonwhite schools in Chicago, Detroit, and New York, areas whose nonwhite proportions varied widely, from 31 to 75 percent. At the other end, blacks were least likely to attend predominantly nonwhite schools in Minneapolis-St. Paul, Riverside, and Orange County. While the first of these had a low nonwhite concentration, the last two had a majority of nonwhite students. 


\section{Where School Segregation was the Most (and Least) Extreme}

Before considering national patterns, it is instructive to identify extreme examples of public school segregation. Using data for 331 metropolitan areas in 1994, I used several measures to rank the areas on the basis of the extent of racial segregation in the public schools. Table 3 gives the top and bottom ten metropolitan areas using the gap-based segregation index. As the table makes quite clear, the most segregated areas differ markedly from the least segregated ones. The metropolitan areas with the highest degree of measured segregation were much larger, had more districts on average, and had vastly higher proportions of nonwhite students. They also include some of the metropolitan areas with the highest degrees of residential segregation. ${ }^{19}$ Areas with the least segregated schools tended to be quite small, and none of them had more than 10 percent nonwhite enrollments.

Table 4 compares the top ten lists arising from eight alternative measures of school segregation. Judging simply from the number of repeated entries, the measures appear to be highly correlated. For example, both the Detroit and Gary areas appear in six of the eight lists, Newark and Jersey City appear on five, and New York, Cleveland, Chattanooga, and Loredo appear in four. California's metropolitan areas are strikingly underrepresented in the entire table. ${ }^{20}$ By contrast, metropolitan areas in Texas are prominent in the last four lists. One likely explanation for this prominence is the very high nonwhite percentages in some of the Texas areas; three of those metropolitan areas had over 90 percent nonwhite enrollment. ${ }^{21}$ This concentration of Texas areas illustrates that of some of these segregation measures are sensitive to overall racial composition, an attribute that the purist might well find objectionable. 
Clotfelter--p.16

\section{$\underline{\text { Patterns of Metropolitan-Area Segregation }}$}

To see how patterns differ among all metropolitan areas, Table 5 presents several measures by size and region. The table's first three columns summarize the racial and ethnic composition of the public school enrollment. They indicate quite clearly that the proportion of blacks and all nonwhites rose with size of metropolitan area. Blacks were most heavily concentrated in the South, Hispanics in the West. Other nonwhites, mostly Asian-Americans, were also most prevalent in the West. Combining all nonwhites, the metropolitan areas in the South and West had the highest proportions. Corresponding to these proportions, exposure rates of whites to nonwhites were highest in the South and West, and they tended to rise with size of metropolitan area.

The exposure rate of black to whites, one measure of racial isolation, shows that black students tended to be in schools with the smallest concentrations of whites in the largest metropolitan areas; by region, however, there was little variation in this measure. Summary measures of segregation are shown in the next three columns. Each of these indicates that the degree of segregation in the public schools tended to increase with the size of the metropolitan area. By region, schools were most segregated in the Midwest and Northeast. In contrast to previous published regional comparisons of segregation, however, the West, and not the South, had the lowest measured segregation values.

Before turning to the table's last column, it is useful to examine in more detail the variation in metropolitan segregation by size and region. Table 6 presents segregation indices based on white-nonwhite differences for all of the size-region combinations. This table shows that regional patterns do vary by size. While the western and southern metropolitan areas were the least 
segregated in the two largest size categories, areas in Border states are in fact the least segregated in the two smallest size categories. The overall regional differences that result, then, reflect the greater population weight of the largest metropolitan areas.

Returning to Table 5, the last column shows the most striking regional variation: the portion of metropolitan segregation (here measured by the Gini coefficient) that can be attributed to within-district segregation, as opposed to disparities between districts. When arrayed by region, it is clear that the metropolitan areas in the South had by far the highest degree of this within-district segregation. The Midwest, which showed the highest overall degree of segregation, had the least. By metro area size, the extent of within-district segregation tended to fall with population. Why did the South have the greatest within-district segregation? One possibility, of course, is that this tendency might simply be a holdover from the segregation practices of the past. Alternatively, the explanation might lie in the lesser degree of jurisdictional fragmentation in the South, as noted by Orfield et al. (1997, pp. 23-24). In fact regional differences in fragmentation did exist, as shown in Table 7. Due in part to the greater use of county-wide districts in the South, the average school jurisdiction in the South was over six times as large as those in the Midwest and Northeast. Assuming that the difficulty of maintaining racial balance increases with district size, the larger average size of districts in the South could well explain that region's greater degree of within-district segregation.

In order to determine whether there existed an independent "regional effect" in segregation levels, it is necessary to hold constant other features of metropolitan areas that might also affect measured segregation. In particular, one should control for metropolitan size, the degree of jurisdictional fragmentation, and racial composition. Table 6 suggests that segregation 
Clotfelter--p.18

levels appeared to rise with metropolitan area size, perhaps reflecting increased racial disparities among districts in large metropolitan areas. Within-district segregation might increase with average district size because of the sheer logistical difficulty of moving students among schools. And, if some minority groups tend to experience more extreme segregation than others, it is important to control for racial composition.

In order to control for such characteristics, regression equations were estimated explaining total segregation for the 331 metropolitan areas in the sample. Shown in Table 8 are equations using the gap-based and Gini-based measures, respectively. Total metropolitan size, measured by the logarithm of metropolitan enrollment, is positive and significant in both equations (8.1) and (8.2), confirming the impression given in Table 6. To give an idea of the magnitude of the size effect, the coefficient in equation (8.2) suggests a 10 percent increase in total metropolitan enrollment would increase the Gini-based segregation index about 1 percent of its mean value. ${ }^{22}$ To repeat, these enrollment patterns result in large part from patterns of residential segregation. Farley and Frey (1994, p. 37), for example, find that black-nonblack residential segregation in 1990 rose with the population of the metropolitan area. Segregation also fell with average district size, suggesting again the potential of larger districts for overcoming segregated residential patterns. The next three coefficients reveal important differences in the segregation of different minority groups. Segregation was most severe where blacks were most numerous. The proportion Hispanic was also associated with more segregation, but the effect was much smaller than for blacks. Segregation in fact fell with the proportion of other nonwhites. Holding these characteristics constant, the regional variables show that the North (the omitted region) and Midwest continued to show the highest levels of segregation, while the South and the West had 
Clotfelter--p.19

the lowest.

\section{SEGREGATION WITHIN DISTRICTS}

Despite its secondary importance in explaining overall school segregation in metropolitan areas, segregation within districts is both an interesting and important topic. Unlike residencebased segregation, reflected in the between-district measures presented in this paper, withindistrict segregation can be largely if not wholly determined by local school authorities. It is useful to ask, therefore, what factors are associated with high levels of within-district segregation. Accordingly, I estimated regressions explaining segregation using districts rather than metropolitan areas as observations, as shown in Table 9. Both the gap-based and Gini-based segregation indices are used as dependent variables. Explanatory variables are included to reflect metropolitan area size and racial composition, as well as region. In the strongest statistical association, district segregation increased with district size. Owing most likely to the increased difficulty of rearranging students as district size increases, larger districts tend to be more segregated. To give a sense of the magnitude of this effect, the coefficients imply that a 10 percent increase in district size would imply an increase in segregation of about 2 percent of its mean value. ${ }^{23}$ District segregation fell with metropolitan enrollment, however, suggesting that the larger a district's share of the entire metropolitan area, the more segregated it was. Consistent with the findings of Table 8 , district segregation increased with the proportion of black students and, to a lesser extent, with the proportion of Hispanic students. To suggest a magnitude for the black proportion effect, an increase of 10 percent in this proportion (from its mean of 0.182 to 0.200) would imply an increase in the $S$ measure of 0.0029 , or about 2.5 percent of that variable's 
Clotfelter--p.20

mean value. The overall racial composition of the metropolitan area had differing effects between the two equations. Among the possible racial composition effects, therefore, the district's own percentage of black students remains the biggest influence, a result that would be consistent with a district policy of attempting to hold onto whites through segregation as the nonwhite population grows.

Once these features are accounted for, some regional differences in district segregation remain. Most notably, the levels of otherwise unexplained segregation remain highest in the South, reinforcing the impression given in Table 5. Other things equal, urban districts in the South tended to be more segregated than those outside the South, though this difference appears to be small.

\section{CONCLUSION}

Although there is general agreement that the most important problems of school segregation are found in metropolitan areas, data limitations have heretofore prevented researchers from systematic measurement of segregation at the metropolitan level. This paper presents measures of segregation for metropolitan areas using the Department of Education's Common Core of Data, a data set covering virtually all public schools. It confirms the prevailing opinion that, not only are metropolitan areas very segregated, most of that segregation is due to racial disparities between districts rather than segregative patterns within districts. It therefore also confirms the extremely limited potential of court-ordered school desegregation, given the prohibition of metropolitan desegregation remedies established by the Milliken v. Bradley decision. Metropolitan areas in the South and West tend to have larger districts, and thus feature 
less fragmentation by school district. This regional difference in fragmentation, which is the product of decades of growth in a federal system of governments and which to some degree characterizes virtually all the major metropolitan areas of the nation, allows for the high degree of residence-based segregation that is evident in metropolitan area school segregation.

Segregation at the metropolitan level appears to vary systematically with size, racial mix, and region. Because larger metropolitan areas tend to have more jurisdictions and exhibit greater differences in racial composition among jurisdictions, measured segregation rises with size, as measured by school enrollment. Larger districts are associated with less segregation, however, since they allow the possibility of mixing students from diverse neighborhoods. These aspects of size held constant, metropolitan areas with higher concentrations of blacks, and to a lesser extent Hispanics, exhibit greater segregation. And, once these factors are accounted for, metropolitan area segregation remains lowest in the South.

At the district level, segregation is greatest in the largest districts, presumably where achieving racial balance is logistically the most difficult. Within-district segregation is also strongly affected by the percentage of students who are black, suggesting that school authorities tend to insulate whites from interracial contact where minority presence is greatest. Finally, districts in the South exhibit higher rates of segregation, other things equal, a finding that stands in contrast to previous regional comparisons in overall segregation. 
Appendix

\section{Illustrative Calculations of Exposure Rates and Several \\ Measures of Segregation}

It is useful to illustrate the calculation of the exposure rate and several measures of segregation with a simple example. Consider a metropolitan area consisting of two districts, A and $\mathrm{B}$, and five schools. Let the enrollments be as follows.

$\begin{array}{ccccc}\text { District } & \text { School } & \text { White } & \text { Nonwhite } & \text { Total } \\ \text { A } & 1 & 80 & 20 & 100 \\ \text { A } & 2 & 90 & 10 & 100 \\ \text { A } & 3 & 50 & 50 & 100 \\ \text { B } & 4 & 90 & 10 & 100 \\ \text { B } & 5 & 100 & 0 & 100\end{array}$
whole.

Summary calculations can be made for each district and for the metropolitan area as a

White enrollment

Nonwhite enrollment

Total enrollment

Percentage nonwhite

Exposure rate $\left(\mathrm{E}_{\mathrm{WN}}\right)$

Gap measure of segregation (S)

$\begin{array}{ccc}\text { District A } & \text { District B } & \text { Metro Area } \\ 220 & 190 & 410 \\ 80 & 10 & 90 \\ 300 & 200 & 500 \\ 26.7 & 5.0 & 18.0 \\ 22.7 & 4.7 & 14.4 \\ 0.15 & 0.06 & 0.20\end{array}$

Note that segregation for the metropolitan area is caused not only by the lack of racial balance among the schools in each district, but also by the disparity in overall racial compositions of the two districts.

The Gini index is calculated by ranking schools from highest to lowest percentage white, plotting the cumulative percentage white on the $\mathrm{x}$-axis against the cumulative percentage nonwhite on the y-axis. Where $i$ denotes schools, the area under the Lorenz curve formed by linking the points corresponding to the cumulative percentages of whites $(\mathrm{CW})$ and nonwhites 
$(\mathrm{CN})$ is:

$$
L=\sum_{i=2}^{I} 0.5\left(C W_{i}-C W_{i-1}\right)\left(C N_{i}-C N_{i-1}\right)
$$

The Gini index is the area between the curve and the diagonal as a percentage of the area under the diagonal (0.5), or:

$\mathrm{G}=(0.5-\mathrm{L}) / 0.5=2(0.5-\mathrm{L})$

For this example the calculated Gini index for the metropolitan area is 0.60 .

Where $\mathrm{W}_{\mathrm{i}}$ and $\mathrm{N}_{\mathrm{i}}$ refer to the number of white and nonwhite students in school $i$, respectively, the index of dissimilarity is calculated as:

$$
D=\left[0.5 \sum_{i}\left|\frac{N_{i}}{N}-\frac{W_{i}}{W}\right|\right] 100
$$

Its value for the metropolitan area in the present example is 46.1 . 
Clotfelter--p.24

\section{References}

Clotfelter, Charles T. 1978. "Alternative Measures of School Desegregation: A Methodological Note.” Land Economics 54 (Aug.):373-380.

Coleman, James S. et al. 1975. "Trends in School Segregation, 1968-73." Urban Institute Paper No. 722-03-01 (Aug.).

DuBois, David L., and Barton J. Hirsch. 1990. "School and Neighborhood Friendship Patterns of Blacks and Whites in Early Adolescence." Child Development 61:524-536.

Ellison, Christopher G., and Daniel A. Powers. 1994. "The Contact Hypothesis and Racial Attitudes among Black Americans." Social Science Quarterly 75 (June):385-400.

Farley, Reynolds, and William H. Frey. 1994. "Changes in the Segregation of Whites from Blacks During the 1980s: Small Steps Toward a More Integrated Society." American Sociological Review 59 (Feb.):23-45.

Hallinan, Maureen T. 1982. "Classroom Racial Composition and Children's Friendships." Social Forces 61 (Sept.):56-72.

Lankford, Hamilton, and James Wyckoff. 1997. "The Effect of School Choice and Residential Location on the Racial Segregation of K-12 Students." Unpublished Paper, University of Albany (June) .

Orfield, Gary. 1983. Public School Desegregation in the United States, 1968-1980. Washington, DC: Joint Center for Political Studies.

Orfield, Gary et al. 1997. "Deepening Segregation in American Public Schools." Harvard Project on School Desegregation, Unpublished Paper, Harvard University (April 5). 
Clotfelter--p.25

Orfield, Gary, and Susan E. Eaton. 1996. Dismantling Desegregation: The Quiet Reversal of

Brown v. Board of Education. New York: The New Press.

Orfield, Gary, and Frank Monfort. 1992. Status of School Desegregation: The Next Generation. Metropolitan Opportunity Project, Harvard University (March).

Rivkin, Steven G. 1994. "Residential Segregation and School Integration." Sociology of Education 67 (Oct.):279-292.

Rossell, Christine H. 1994. "The Progeny of Brown: From the Old Freedom of Choice to the New Freedom of Choice in Four Decades." Urban Geography 15:435-453.

Rossell, Christine H., and David Armor. 1996. "The Effectiveness of School Desegregation Plans, 1968-1991.” American Politics Quarterly 24 (July):267-302.

Welch, Finis, and Audrey Light. 1987. New Evidence on School Desegregation. Washington: United States Commission on Civil Rights (June). 


\section{Endnotes}

1. See, for example, Orfield and Montford (1992) and Rivkin (1994). For data on the most recent trends, see Orfield et al. (1997) or Lankford and Wyckoff (1997).

2. The only paper to my knowledge that examines data for metropolitan areas is Lankford and Wyckoff (1997), which focuses on data for eight metropolitan areas in New York as part of an analysis of school choice and racial segregation.

3. For contrasting assessments of desegregation policy, see Orfield and Eaton (1996) and Rossell (1994).

4. For examples of studies of the effect of interracial contact, see Hallinan (1982), DuBois and Hirsch (1990), or Ellison and Powers (1994).

5. For a description of the Texas law, see, for example, Peter Applebome, "Seeking New Approaches for Diversity," New York Times, April 23, 1997, p. A19.

6. The purely statistical measures used in this paper should not be viewed as comprehensive measures of desegregation policy. Among other reasons, there is evidence that mandatory desegregation plans may have different effects on the behavior of whites than voluntary plans (Rossell and Armor 1996).

7. See, for example, Farley and Frey (1994).

8. See, for example, Orfield (1983), Welch and Light (1987), Orfield and Monfort (1992), Rivkin (1994), and Orfield et al. (1997).

9. Orfield and Monfort (1992, p. 12) complain about the incompleteness, sampling problems, and delay in dissemination of the OCR data. "The surveys tend to [include] districts with large minority populations but not traditionally white districts. This often makes it impossible to look 
at urban areas as a whole, particularly in the highly fragmented metropolitan areas of the Northeast and Midwest."

10. Data on racial and ethnic enrollments were not reported by the state of Idaho or the St. Joseph, Missouri school district, which necessitated the omission of three metropolitan areas. 11. As is the common practice in this literature, "white" refers to non-Hispanic white; therefore "nonwhite" includes all Hispanics.

12. The Appendix provides formulas for those measures not discussed in the text, along with a simple example to illustrate the calculations of the measures used in the paper.

13. This measure, denoted $\mathrm{R}$, is used by Coleman et al. (1975). For a discussion of this measure and its relationship to measures of exposure, see Clotfelter (1978). For an illustration of the calculation of this measure, and the underlying exposure rates, Appendix A of the paper presents a simple example.

It is useful to note that the value of $\mathrm{S}$ is invariant with respect to which of two groups is used as the basis for calculating the exposure rate. That is, $\mathrm{S}$ can be calculated using the exposure of nonwhites to whites, where $\mathrm{W}$, the overall percentage of students who are white, is the maximum for this exposure rate: $\mathrm{S}=\left(\mathrm{W}-\mathrm{E}_{\mathrm{NW}}\right) / \mathrm{W}$.

14. To assess the difference made by alternative groupings, Gini-based segregation indices were calculated for the 331 metropolitan areas using three different breakdowns: whites versus nonwhites, as presented in the paper, nonblacks versus blacks, and whites and other nonwhites versus blacks and Hispanics. Three tables of the form of Table 6 were formed showing the average segregation rates by size and region. Rankings were made by region within size categories and by size within regions to see if the cell with the highest index measured one way was also the highest when measured the other two ways; similar rankings were made for the 
lowest segregation index in each group. Of the 18 possible comparisons, the ranking was not affected by which of the three groupings were used in 13 cases. Of the 20 size-region cells, public schools were least segregated in the smallest metropolitan areas in the West, the conclusion being the same with Gini indices based on each one of the three groupings, the calculated indices being $0.41,0.47$, and 0.44 , respectively. Schools were most segregated in the largest metropolitan areas of the Midwest, again no matter which of the three groupings were used; calculated indices were $0.84,0.91$, and 0.88 , respectively.

15. The numbers of metropolitan areas in each size and region category are shown in Table A1. 16. Following Orfield and Monfort (1992, p. 2), the regions were defined as follows: South: Alabama, Arkansas, Florida, Georgia, Louisiana, Mississippi, North Carolina, South Carolina, Tennessee, Texas, Virginia; Border: Delaware, District of Columbia, Kentucky, Maryland, Missouri, Oklahoma, West Virginia; Northeast: Connecticut, Maine, Massachusetts, New Hampshire, New Jersey, New York, Pennsylvania, Rhode Island, Vermont; Midwest: Illinois, Indiana, Iowa, Kansas, Michigan, Minnesota, Nebraska, North Dakota, South Dakota, Ohio, Wisconsin; West: Arizona, California, Colorado, Idaho, Montana, Nevada, New Mexico, Oregon, Utah, Washington, Wyoming. The 13 metropolitan areas (MSA or PMSA) that had components from more than one region were classified it in the region containing the largest enrollment. 17. The sample excludes special, vocational, or alternative schools, and districts operated by the state or federal government. In the terms defined in the data set, the present sample includes type 1 (regular) schools and districts of types 1-4. In 1994 the excluded districts contained less than 0.4 percent of all public school students.

18. It is tempting to apply Rivkin's term, "residential segregation," to this portion, but to do so might obscure the very obvious fact that residential segregation also exists within school districts. 
19. Farley and Frey (1994, p. 33) rank metropolitan areas in 1990 by the extent of black-nonblack residential segregation, using the dissimilarity index. Of the ten most segregated metropolitan areas shown in Table 3 of the current paper, four also appeared among the top 10 in residential segregation.

20. One possible explanation for this result is suggested by the regression below showing more severe segregation associated with blacks and Hispanics, which implies less segregation in the presence of Asian-Americans, who tend to be more numerous in California.

21. Loredo, McAllen, and Brownsville.

22. Multiplying the $\log$ difference in enrollments $(\ln (1.1)=0.095)$ by the coefficient 0.070 yields 0.0067 , or about 1 percent of the mean of the Gini measure 0.671 .

Farley and Frey (1994, p.37) similarly find that black-nonblack residential segregation in 1990 rose with the population of the metropolitan area.

23. A 10 percent increase in district size increases the logarithm of district size by 0.095 . Applying the coefficient in (9.1) yields an effect of 0.00257 , or 2.5 percent of the mean for S of 0.103 . Equation (9.2) implies a change equal to 1.9 percent of the mean for the Gini-based measure. 


\section{Table 1}

Public School Enrollment by Race

Washington, D.C. MSA, 1994

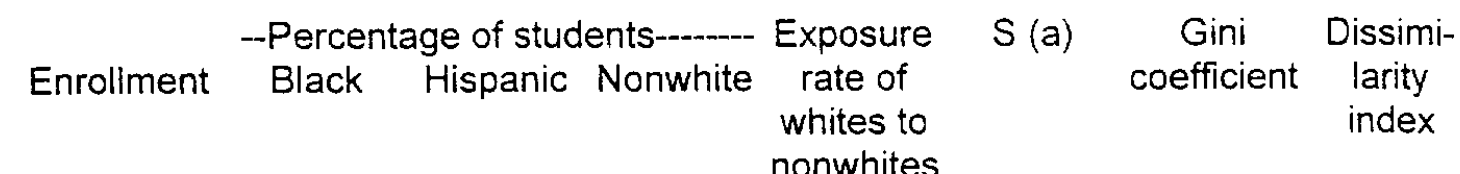

District

(2)

(3)

(4)

(5)

(6)

(7)

(8)

$\begin{array}{lrrrrrrrr}\text { All districts } & 623,655 & 34.8 & 7.7 & 49.8 & 30.1 & 0.40 & 0.71 & 55 \\ & & & & & & & & \\ \text { District of Columbia } & 77,662 & 87.8 & 6.8 & 96.0 & 50.0 & 0.48 & 0.95 & 86 \\ \text { Calvert Co. } & 12,756 & 17.2 & 0.5 & 18.4 & 17.9 & 0.03 & 0.22 & 17 \\ \text { Charles Co. } & 20,291 & 24.6 & 1.3 & 28.6 & 27.9 & 0.02 & 0.18 & 12 \\ \text { Frederick Co. } & 31,390 & 7.4 & 1.4 & 10.4 & 9.4 & 0.10 & 0.53 & 44 \\ \text { Montgomery Co. } & 116,111 & 18.8 & 11.5 & 43.1 & 37.2 & 0.14 & 0.43 & 30 \\ \text { Prince Georges Co. } & 116,305 & 70.4 & 5.1 & 80.0 & 61.8 & 0.23 & 0.63 & 48 \\ \text { Alexandria City } & 9,664 & 48.6 & 18.2 & 73.1 & 70.5 & 0.04 & 0.21 & 14 \\ \text { Arlington Co. } & 16,854 & 18.0 & 29.6 & 57.3 & 44.4 & 0.23 & 0.54 & 43 \\ \text { Fairfax Co. } & 135,409 & 10.9 & 8.6 & 32.8 & 28.7 & 0.12 & 0.41 & 30 \\ \text { Falls Church City } & 1,356 & 4.7 & 10.1 & 20.5 & 20.3 & 0.01 & 0.14 & 11 \\ \text { Loudoun Co. } & 18,131 & 8.6 & 3.1 & 15.9 & 15.3 & 0.04 & 0.29 & 21 \\ \text { Manassas City } & 5,408 & 15.8 & 7.1 & 27.2 & 26.4 & 0.03 & 0.17 & 14 \\ \text { Manassas Park City } & 1,490 & 10.7 & 6.3 & 20.5 & 20.3 & 0.01 & 0.11 & 9 \\ \text { Prince William Co. } & 45,369 & 19.4 & 5.6 & 29.1 & 26.6 & 0.09 & 0.37 & 28 \\ \text { Stafford Co. } & 15,459 & 9.7 & 1.7 & 13.1 & 12.9 & 0.02 & 0.20 & 14\end{array}$

(a) Gap between maximum and actual exposure rate of whites to nonwhites as a proportion of the maximum rate $([(4)-(5)] /(4))$.

Source: Department of Education, Common Core of Data; author's calculations.

123lximetroim1a

$8 / 26 / 97$ 


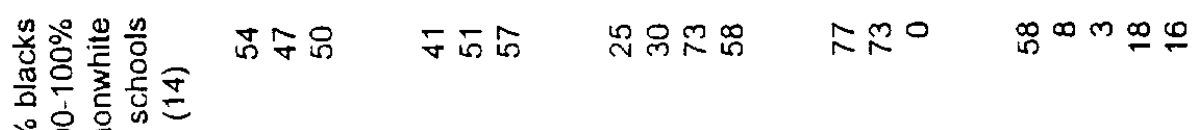

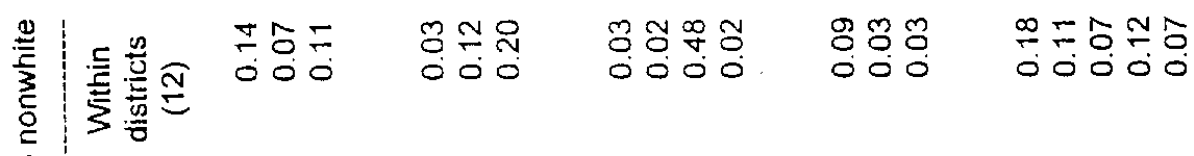

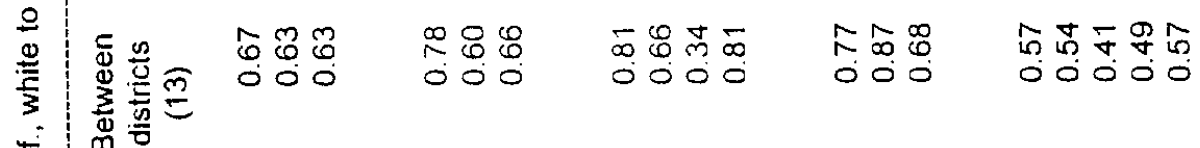

宽

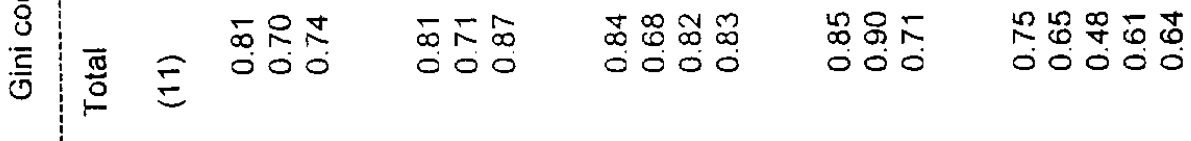

क

帝

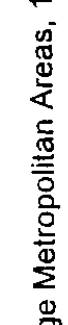

ब्र 100 兽

एँ

袬品

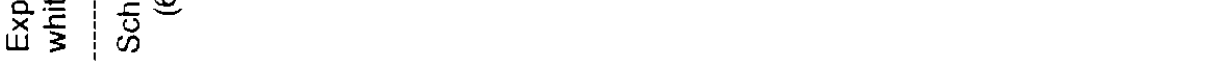

ए

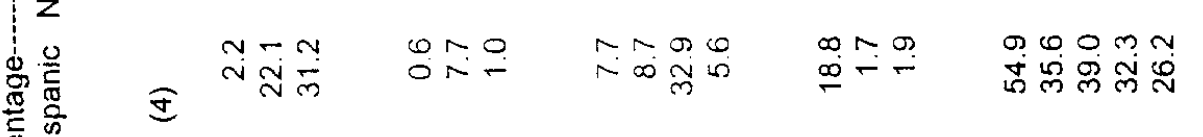

可

道 त

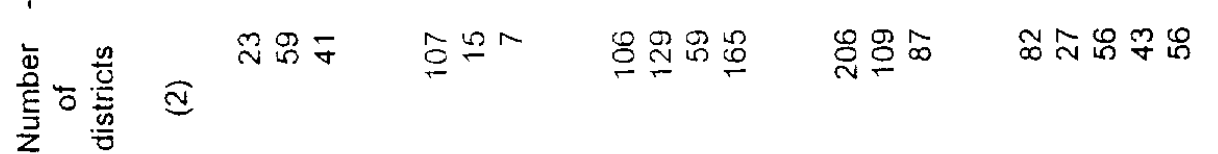

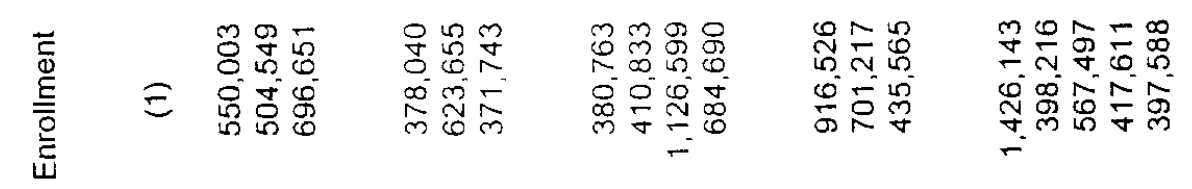

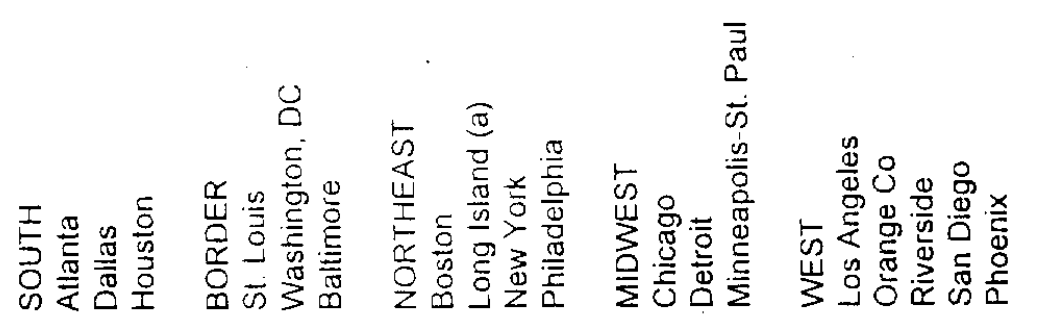

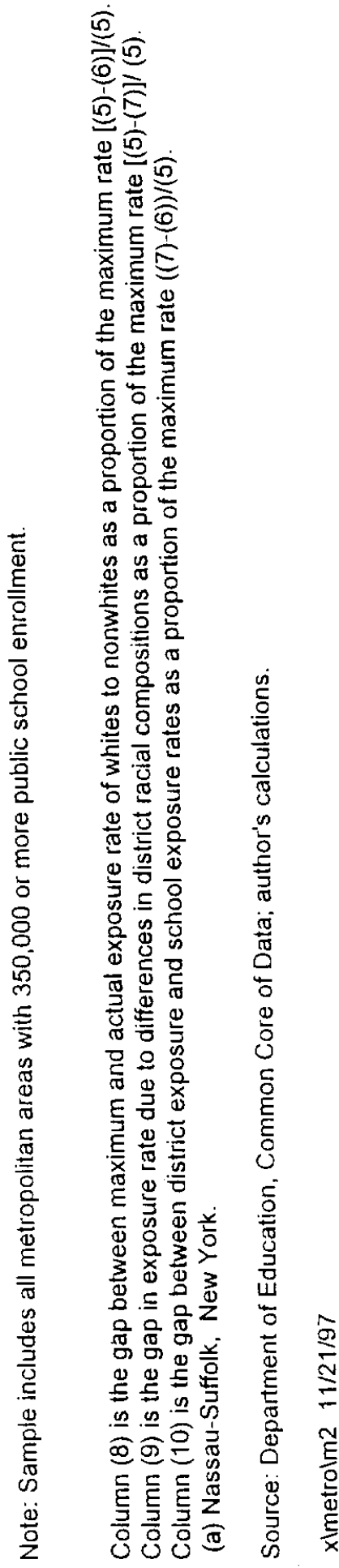




\section{Table 3}

The Most and Least Segregated Metropolitan Areas,

Based on Relative Gap Measure (S)

Metropolitan area

$S$

Percent

Enrollment

Number of

nonwhite districts

Most segregated

Detroit, M!

0.71

30.7

701,217

109

Gary, IN

0.67

36.0

110,846

Birmingham, AL

37.6

157,258

17

Newark, NJ

35.1

Chattanooga, TN

0.61

64,809

70,015

0.61

20.9

268,063

0.59

33.3

269,970

46.3

118,239

31.9

81,631

48.1

28,770

Least segregated

Glens Falls, NY

0.01

2.0

3.1

22,840

21

0.01

12,814

St. Cloud, MN

0.02

2.3

40,241

16

0.02

1.8

26,243

2.7

14,341

Lewiston-Auburn, ME

0.02

8.9

46,669

0.02

Bristol, CT

9.9

10,440

0.02

2.7

21,263

2.9

36,777

0.02

3.1

12,222

Source: Common Core of Data; author's calculations.

M7 9/3/97 


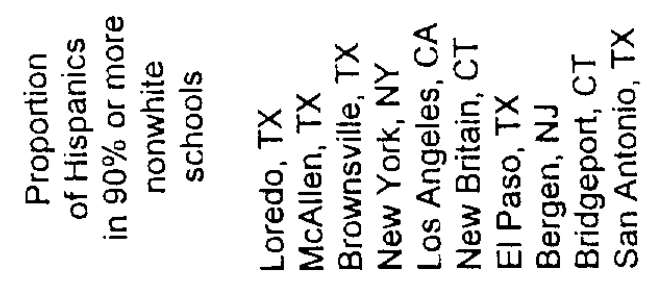

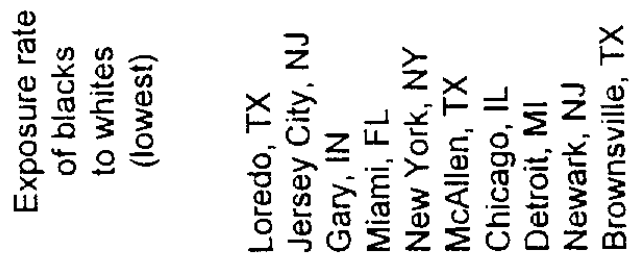

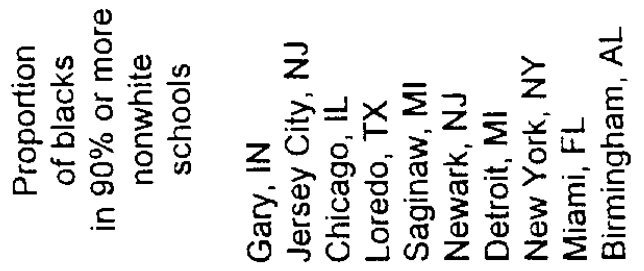

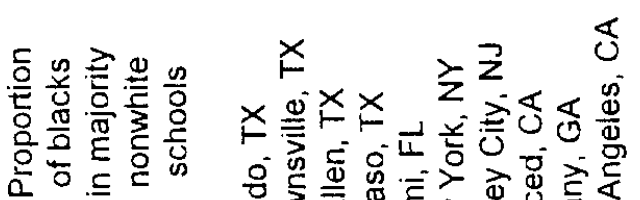

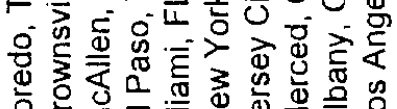

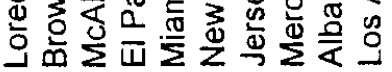

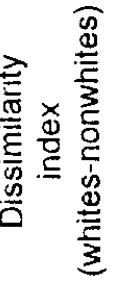

T

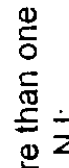

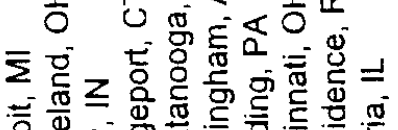

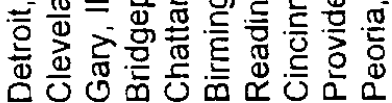

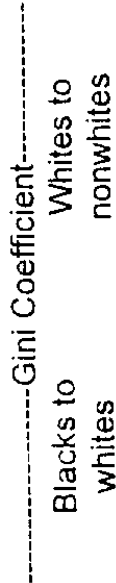

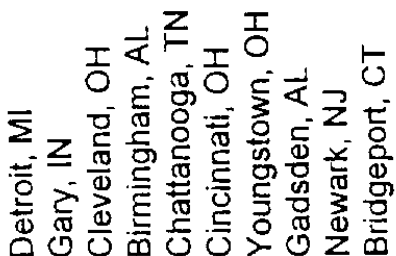

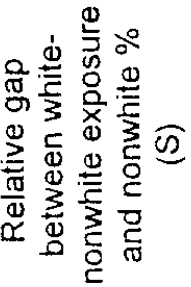

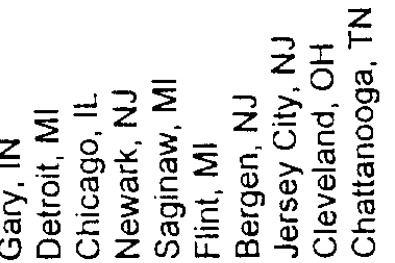

送它

茨㖞

空

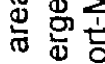

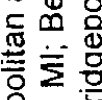

웅

过的

خ捾

部罂

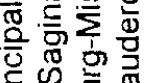

心

$\frac{\overbrace{0}^{n}}{\frac{0}{\pi}}$

उठㅇㅎㅁ

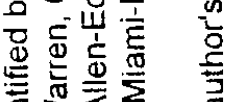

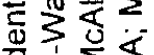

일

$\frac{\pi}{0}$

苋界灾

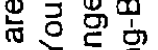

蛋

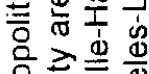

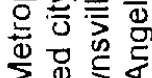

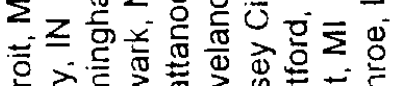

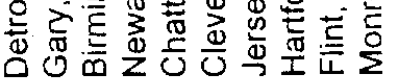

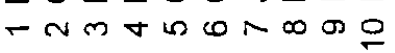

至空总员

$\hat{a}$
के
ڤ્ 
峷总醇可

$\stackrel{\infty}{\leftarrow} \pm$

Оं००⿱一兀

舟오요

o. 0 0。

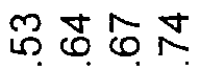

०००००

으욤

००००

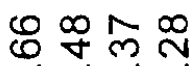

O०००0

즌ำ

잉ํㅇ

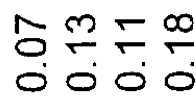

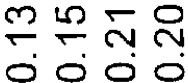

ลิ

势

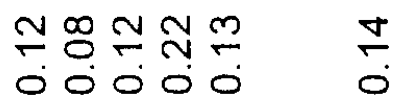

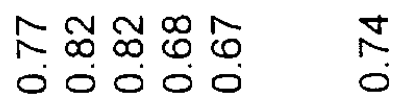

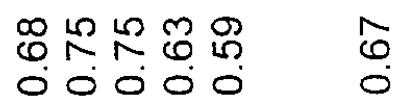

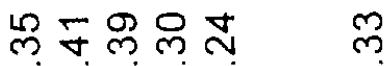

००000

ซㅝำ ₹

000000

뮤윻유

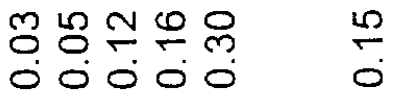

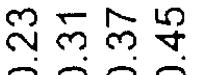

0000

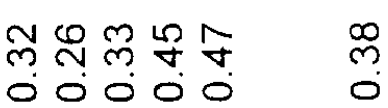

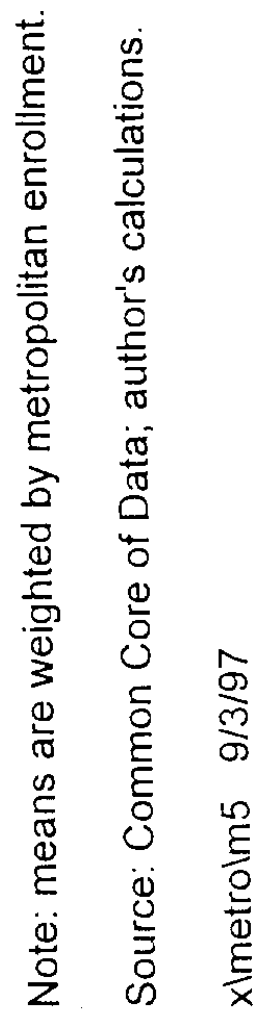




\section{Table 6}

Average Gap-Based Segregation Index (S) in Metropolitan Areas, by Size and Region, 1994

Region

\begin{tabular}{rrrr} 
Metropolitan Public School Enrollment \\
\hline $\begin{array}{r}\text { Under } \\
50,000\end{array}$ & $\begin{array}{r}150,000 \\
\text { under }\end{array}$ & $\begin{array}{r}350,000 \\
\text { under }\end{array}$ & or more \\
& 150,000 & 350,000 &
\end{tabular}

All

$\begin{array}{llllll}\text { Border } & 0.08 & 0.16 & 0.36 & 0.47 & 0.35 \\ \text { Midwest } & 0.17 & 0.34 & 0.47 & 0.56 & 0.41 \\ \text { Northeast } & 0.18 & 0.39 & 0.46 & 0.46 & 0.40 \\ \text { South } & 0.20 & 0.26 & 0.31 & 0.43 & 0.30 \\ \text { West } & 0.13 & 0.20 & 0.24 & 0.29 & 0.24\end{array}$
All
0.16
0.29
0.34
0.42
0.33

Note: means are weighted by metropolitan enrollment.

Source: Common Core of Data; author's calculations.

$x \backslash$ metrolm3b $9 / 3 / 97$ 
Table 7

Average Enrollment per District, by Size and Region, 1994

Region

\begin{tabular}{crrr} 
Metropolitan Public School Enrollment \\
\hline Under & $\begin{array}{r}50,000 \\
\text { under } \\
150,000\end{array}$ & $\begin{array}{r}150,000 \\
\text { under } \\
350,000\end{array}$ & $\begin{array}{l}350,000 \\
\text { or more }\end{array}$
\end{tabular}

All

Border

7,320

6,570

3,957

34,226

21,019

Midwest

3,419

3,733

4,594

5,245

4,345

Northeast

3,023

3,332

2,697

10,385

6,062

South

14,532

24,916

64,000

16,734

35,662

West

8,034

10,862

20,805

13,503

14,776

All

$7,221 \quad 10,998$

29,786

14,037

17,310

Note: figures are unweighted averages.

Source: Common Core of Data; author's calculations.

ximetrolm3e $\quad 9 / 3 / 97$ 
Regressions Explaining Total Segregation, 331 Metropolitan Areas, 1994

Equation

Dependent

variable

Explanatory

variable

Intercept

In (metropolitan enrollment)

In (enrollment per district)

Proportion black

Proportion Hispanic

Proportion other nonwhite

South

Border

Midwest

West

R-squared
8.1

8.2
Total segregation Total segregation

(S)

(Gini)
-0.259 *

0.074 *

(11.3)

-0.041 *

(5.3)

$-0.033^{*}$

(4.4)

0.667 *

(10.6)

0.386 *

0.089 *

(2.1)

0.122 *

$-0.280$

(1.6)

-0.380 *

(2.2)

-0.102 *

(4.6)

-0.117 *

-0.094 *

-0.086 *

(3.4)

$-0.015$

(0.8)

$-0.006$

(0.4)

-0.078 *

-0.140 *

(6.4)

0.59

0.56

Notes:

Dependent variable in equation (8.1) is gap based on whites and nonwhites; see text. Dependent variable in (8.2) is Gini coefficient of segregation of whites from nonwhites. Numbers in parentheses are t-statistics.

Asterisks indicate coefficients significantly different from zero at $p=0.05$.

Regressions are weighted by the square root of metropolitan enrollment.

Omitted region is Northeast. For definitions, see text.

Source: Common Core of Data; author's calculations.

ximetrolm4; metro1.run; 11/19/97.

$7 / 26 / 98$ 
Regressions Explaining Segregation within Urban School Districts,
5,802 School Districts, 1994

Equation

Dependent variable

Explanatory

variable

Intercept

In (district enrollment)

In (metropolitan enrollment)

District proportion black

District proportion Hispanic

District proportion other nonwhite

Metropolitan proportion nonwhite

South

Border

Midwest

West

R-squared
9.1

Segregation (S) Segregation (Gini)
-0.151 *

(15.8)

0.027 *

(41.9)

-0.005 *

(6.4)

0.161 *

$0.025 *$

(4.4)

0.025

(1.8)

0.024 *

0.009 *

0.005

(1.5)

0.002

(0.8)

0.003

(1.1)

0.51
-0.324 *

(15.3)

0.076 *

-0.008 *

0.229 *

0.143 *

-0.081 *

(2.7)

-0.074 *

0.022 *

0.036 *

0.034 *

(7.2)

$-0.008$

0.51

Notes:

Dependent variable in (9.1) is gap based on whites and nonwhites; see text. Dependent variable in (9.2) is Gini coefficient of segregation of whites from nonwhites.

Numbers in parentheses are t-statistics.

Asterisks indicate coefficients significantly different from zero at $p=0.05$.

Regressions are weighted by the square root of district enrollment.

Omitted region is Northeast. For definitions, see text.

Source: Common Core of Data; author's calculations.

XImetrolm8; dist.run; $2 / 17 / 98$

$7 / 27 / 98$ 


\section{Table A1}

Number of Metropolitan Areas by Size and Region, 1994

Metropolitan Public School Enrollment

\begin{tabular}{|c|c|c|c|}
\hline \multicolumn{4}{|c|}{ Metropolitan Public School Enrollment } \\
\hline $\begin{array}{l}\text { Under } \\
50,000\end{array}$ & $\begin{array}{r}50,000 \\
\text { under } \\
150,000\end{array}$ & $\begin{array}{r}150,000 \\
\text { under } \\
350,000\end{array}$ & $\begin{array}{l}350,000 \\
\text { or more }\end{array}$ \\
\hline
\end{tabular}

Region

$\begin{array}{llrrrr}\text { Border } & 11 & 5 & 2 & 3 & 21 \\ \text { Midwest } & 49 & 21 & 6 & 3 & 79 \\ \text { Northeast } & 38 & 21 & 5 & 4 & 68 \\ \text { South } & 61 & 27 & 16 & 3 & 107 \\ \text { West } & 24 & 17 & 10 & 5 & 56\end{array}$

$\begin{array}{llllll}\text { All } & 183 & 91 & 39 & 18 & 331\end{array}$

Source: Common Core of Data.

xImetrolm3c $9 / 3 / 97$

$7 / 27 / 98$ 